\title{
Fluorescence Sensing Properties of Thiazolobenzo-crown Ether Incorporating Coumarin
}

\author{
Sang Hoon Lee, Aasif Helal, and Hong-Seok Kim* \\ Department of Applied Chemistry, Kyungpook National University, Daegu 702-701, Korea. *E-mail: kimhs@knu.ac.kr \\ Received September 29, 2009, Accepted October 21, 2009
}

\begin{abstract}
A new coumarin-thiazolobenzo-crown ether based fluorogenic chemosensor BTC (1) was reported. The ion-selective binding properties of 1 with different alkali, alkaline earth metals and transitional metals were investigated in an ethanolDMSO system. BTC (1) showed the highest binding constant toward $\mathrm{Hg}^{2+}$ over $\mathrm{Ag}^{+}, \mathrm{Pb}^{2+}$ and $\mathrm{Cu}^{2+}$.
\end{abstract}

Key Words: Thiazolobenzo-crown ether, Coumarin, Fluorescence sensor, Mercury ion

\section{Introduction}

A macrocycle that possesses ionophoric ability has been a subject of extensive investigation not only for its synthetic protocol but also for its potential applications since its discovery by Pedersen. ${ }^{1}$ There is a growing interest in synthesizing crown ether derivatives with fluorescence properties showing marked changes upon metal complexation, aiming to develop ion-selective and sensitive material. ${ }^{2}$ Crown ethers that contain thiazole moieties have been reported to exhibit a large degree of ammonium ion selectivity. ${ }^{3}$ Recently thiazolobenzo-crown ether incorporated with a naphthalene moiety has been used for selective detection of $\mathrm{Ag}^{+}$over $\mathrm{Hg}^{2+}, \mathrm{Pb}^{2+}$ and $\mathrm{Cu}^{2+}$.

Coumarins are relatively photo-stable and their excitation and emission maxima, in many cases, are long enough to minimize the so-called "background" fluorescence of cellular components, tissues and biological fluids. ${ }^{5}$ Therefore, coumarins are used in the fields of biology, medicine, perfumes, cosmetics and laser dyes. ${ }^{6}$ They exhibit Stokes shifts large enough to avoid significant overlap of the excitation and emission spectra and the fluorescence quantum yields allow for ion detection at low indicator concentrations. ${ }^{7}$ By the integration of coumarin chromophore in crown ethers, coumarin and its analogues have been extensively used in metal ion detection. ${ }^{8-10}$

Fluorescent sensors for the detection of heavy metals such as mercury, cadmium and lead are of growing interest due to their bioaccumulation, biomagnification and persistence in the environment. An especially active area of current growth is the detection of mercury ions with optical probes. ${ }^{11}$ Bacteria-mediated organomercury accumulates in higher organisms and has been implicated as a cause of prenatal brain damage, ${ }^{12}$ various cognitive and motion disorders, ${ }^{13}$ or Minamata disease. ${ }^{14}$ Therefore, it is of considerable importance to sense the presence of lethal mercury ions with a cost-effective, facile and biologically applicable detection method. Some $\mathrm{Hg}^{2+}$ sensors were reported that were based on moieties of azo-derivatives, ${ }^{15,16} \mathrm{~N}$-dansylcarboxamide,${ }^{17}$ thiocoumarin, ${ }^{18}$ calixarene, ${ }^{19}$ thiocarbamate, ${ }^{20}$ rhodamine, ${ }^{11 \mathrm{~d}, 21}$ anthraquinone, ${ }^{22}$ porphyrin $^{23}$ and fluorescein. ${ }^{24}$ Accordingly, macrocycles bearing suitable light sensitive moi-

${ }^{\dagger}$ This paper is dedicated to Professor Sunggak Kim on the occasion of his honourable retirement. eties such as coumarin may undergo intermolecular changes at the electronic level upon following the cation dipole interactions of the oxygen donors. Therefore the alterations in the fluorescence spectra of fluorogenic macrocycles in the presence of ions would be a good measure of ion dipole interactions. ${ }^{25-27}$

This paper is the account of the synthesis of a coumarin-thiazolobenzo-crown ether based mercury selective chemosensor that was developed by introducing a coumarin moiety as a potential fluorophore near the binding site of the thiazolobenzo-crown ether moiety. The absorption and emission properties of the sensor were investigated with different cations in ethanol:DMSO $(\mathrm{v} / \mathrm{v}, 9: 1)$. The importance of the close ring structure of coumarin-thiazolobenzo-crown ether in the sensing of $\mathrm{Hg}^{2+}$ was also studied.

\section{Experimental Section}

Melting points were determined using a Thomas-Hoover capillary melting point apparatus and were uncorrected. ${ }^{1} \mathrm{H}$ and ${ }^{13} \mathrm{C}$ NMR spectra were recorded on a Bruker AM-400 spectrometer using $\mathrm{Me}_{4} \mathrm{Si}$ as the internal standard. UV-vis absorption spectra were determined on a Shimadzu UV-1650PC spectrophotometer. Fluorescence spectra were measured on a Shimadzu RF-5301 fluorescence spectrometer equipped with a xenon discharge lamp, $1 \mathrm{~cm}$ quartz cells. All of the measurements were carried out at $298 \mathrm{~K}$.

Analytical grade absolute ethanol and DMSO were purchased from Merck. All other materials used for the synthesis were purchased from Aldrich Chemical Co. and were used without further purification. 6,7-Dimethoxycoumarin ${ }^{28} \mathbf{3}$ and 2,3-bis [2(4-chloromethyl)thiazolyl]-methyloxybenzene 4 and [2(4chloromethyl)thiazolyl)]methyloxybenzene $\mathbf{5}$ were prepared according to the cited procedure. ${ }^{3}$ The solutions of metal ions were prepared from their perchlorate salts of analytical grade and then subsequently diluted to prepare working solutions.

Synthesis of BTC (1). A mixture of esculetin (163 mg, 0.914 $\mathrm{mmol})$ and $\mathrm{K}_{2} \mathrm{CO}_{3}(283 \mathrm{mg}, 2.04 \mathrm{mmol})$ in 2-butanone $(50 \mathrm{~mL})$ was heated at $60{ }^{\circ} \mathrm{C}$ for $30 \mathrm{~min}$. A solution of $4(300 \mathrm{mg}, 0.747$ $\mathrm{mmol})$ and $\mathrm{NaI}(246 \mathrm{mg}, 1.60 \mathrm{mmol})$ in 2-butanone $(5 \mathrm{~mL})$ was added to the resulting mixture and refluxed for $12 \mathrm{~h}$. The solvent was removed under reduced pressure and the residue was ex- 
tracted with EtOAc. The organic layer was washed, dried over anhydrous $\mathrm{Na}_{2} \mathrm{SO}_{4}$ and concentrated. The residue was purified by $\mathrm{SiO}_{2}$ column chromatography (EtOAc:hexane $\left.=2: 1\right)$ to give 1 in a $70 \%$ yield. mp $249-250{ }^{\circ} \mathrm{C}\left(\mathrm{CH}_{2} \mathrm{Cl}_{2}\right.$ - hexane $) ;{ }^{1} \mathrm{H}$ NMR $\left(400 \mathrm{MHz}, \mathrm{DMSO}-d_{6}\right) \delta 5.07(\mathrm{~s}, 2 \mathrm{H}), 5.15(\mathrm{~s}, 2 \mathrm{H}), 5.21(\mathrm{~s}, 2 \mathrm{H})$, $5.23(\mathrm{~s}, 2 \mathrm{H}), 6.31(\mathrm{~d}, J=9.4 \mathrm{~Hz}, 1 \mathrm{H}), 6.97-6.99(\mathrm{~m}, 2 \mathrm{H}), 7.14-$ $7.24(\mathrm{~m}, 2 \mathrm{H}), 7.24(\mathrm{~s}, 1 \mathrm{H}), 7.41(\mathrm{~s}, 1 \mathrm{H}), 7.82(\mathrm{~s}, 1 \mathrm{H}), 7.83(\mathrm{~s}$, $1 \mathrm{H}), 7.93(\mathrm{~d}, J=9.6 \mathrm{~Hz}, 1 \mathrm{H}) ;{ }^{13} \mathrm{C}$ NMR $\left(100 \mathrm{MHz}, \mathrm{DMSO}-d_{6}\right)$ $\delta 66.1,66.2,66.4,66.6,101.7,110.7,112.2,113.7,114.2,114.3$, $122.2,122.3,122.4,122.8,145.2,145.8,148.4,148.5,150.4$, 152.0, 152.4 152.5, 161.5, 164.3, 164.5; Anal. Calcd for: $\mathrm{C}_{25}$ $\mathrm{H}_{18} \mathrm{~N}_{2} \mathrm{O}_{6} \mathrm{~S}_{2}$ : C, 59.28; H, 3.58; N, 5.53; S, 12.66; Found C, 59.22; H, 3.77; N, 5.12; S, 12.83 .

Synthesis of OTC (2). This compound was obtained from the reaction of esculetin $(178 \mathrm{mg}, 0.56 \mathrm{mmol})$ with $\mathbf{5}(296 \mathrm{mg}$, $1.23 \mathrm{mmol})$ and $\mathrm{NaI}(221 \mathrm{mg}, 1.48 \mathrm{mmol})$ in the presence of $\mathrm{K}_{2} \mathrm{CO}_{3}(170 \mathrm{mg}, 1.25 \mathrm{mmol})$ in 2-butanone $(50 \mathrm{~mL})$. After work up, the crude product was purified by $\mathrm{SiO}_{2}$ column chromatography (EtOAc:hexane $=1: 3$ ) to give 2 in a 68\% yield. mp 172 ${ }^{\circ} \mathrm{C}\left(\mathrm{CH}_{2} \mathrm{Cl}_{2}\right.$-hexane); ${ }^{1} \mathrm{H}$ NMR (400 MHz, DMSO- $\left.d_{6}\right) \delta 5.20$ (s, $2 \mathrm{H}), 5.31(\mathrm{~s}, 2 \mathrm{H}), 5.21(\mathrm{~s}, 2 \mathrm{H}), 5.40(\mathrm{~d}, J=2.2 \mathrm{~Hz}, 4 \mathrm{H}), 6.30(\mathrm{~d}$, $J=9.4 \mathrm{~Hz}, 1 \mathrm{H}), 6.95-6.99(\mathrm{~m}, 2 \mathrm{H}), 7.03(\mathrm{~d}, J=8.1 \mathrm{~Hz}, 4 \mathrm{H})$, 7.27-7.30 (m, 5H), $7.44(\mathrm{~s}, 1 \mathrm{H}), 7.77(\mathrm{~s}, 1 \mathrm{H}), 7.84(\mathrm{~s}, 1 \mathrm{H}), 7.91$ $(\mathrm{d}, J=9.6 \mathrm{~Hz}, 1 \mathrm{H}) ;{ }^{13} \mathrm{CNMR}\left(100 \mathrm{MHz}, \mathrm{DMSO}-d_{6}\right) \delta 60.0,66.5$, $66.8,66.9,102.1,112.0,112.1,113.4,115.2,115.8,119.7$, 120.0, 120.3, 120.5, 121.8, 130.0, 144.5, 145.0, 149.88, 151.14, 151.7, 151.8, 157.9, 160.8, 167.2, 167.4; Anal. Calcd for: $\mathrm{C}_{31^{-}}$ $\mathrm{H}_{24} \mathrm{~N}_{2} \mathrm{O}_{6} \mathrm{~S}_{2}: \mathrm{C}, 63.68 ; \mathrm{H}, 4.14 ; \mathrm{N}, 4.79 ; \mathrm{S}, 10.97$; Found C, 63.65; H, 4.46; N, 4.49; S, 10.67 .

\section{Results and Discussion}

The chemosensors BTC (1) and OTC (2) were prepared in good yields by reacting $\mathbf{4}$ and $\mathbf{5}$ respectively with esculetin in 2-butanone and $\mathbf{3}$ was prepared by simple methylation of esculetin. ${ }^{29}$ The structures of $\mathbf{1}, \mathbf{2}$ and $\mathbf{3}$ were confirmed by ${ }^{1} \mathrm{H}$ NMR, ${ }^{13} \mathrm{C}$ NMR and the elemental analyses data.

The cation-binding properties of BTC (1) were investigated by observing the changes in its absorption and emission spectrum, in a mixed ethanol and DMSO (v/v, 9:1) system. An initial UV-vis study of 1 showed that it produced a peak at $340 \mathrm{~nm}$ with a high molar absorption co-efficient $\left(\varepsilon>10^{4} \mathrm{~cm}^{-1} \mathrm{M}^{-1}\right)$ indicating that the absorption band was due to $\pi-\pi *$ transitions, on the slow addition of $\mathrm{Hg}^{2+}$ there was a blue shift of $9 \mathrm{~nm}$ (Figure 2).

This blue shift was only noticed in $\mathrm{Hg}^{2+}$ and a little in $\mathrm{Ag}^{+}$ $(6 \mathrm{~nm})$, none of the other ions including $\mathrm{Cd}^{2+}$ and $\mathrm{Pb}^{2+}$ revealed such a blue shift (Figure 3).
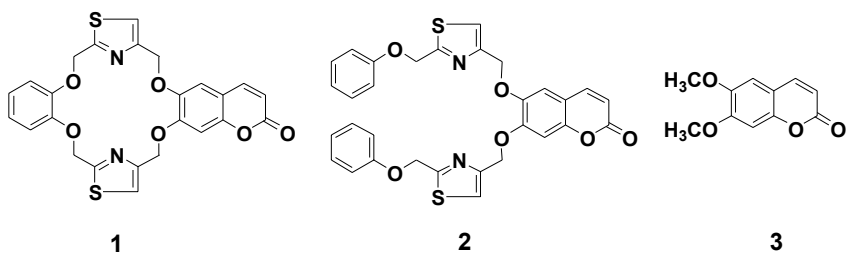

Figure 1. Structure of BTC (1), OTC (2), and dimethoxycoumarin (3).
The sensor 1 produced an emission spectrum at $428 \mathrm{~nm}$ on excitation at $329 \mathrm{~nm}$ due to the intramolecular charge transfer (ICT) from the oxygen donor of the thiazolobenzo-crown ether to the carbonyl group of the coumarin moiety (Table1). The binding of $\mathrm{Hg}^{2+}$ with the oxygen of the crown ether reduces the
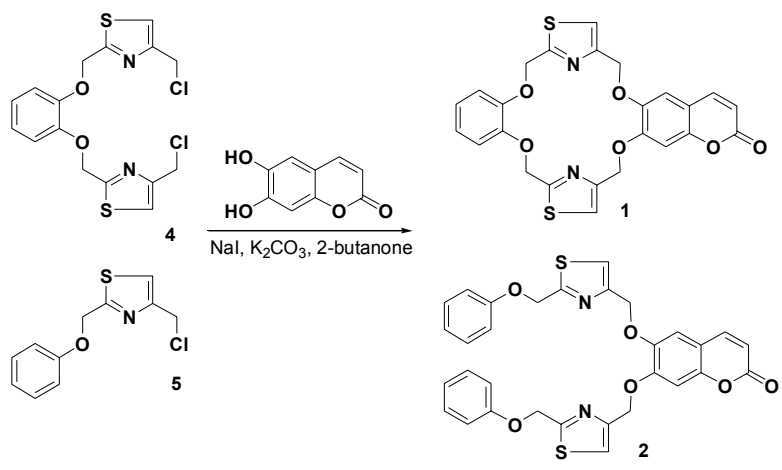

Scheme 1. Synthesis of BTC (1) and OTC (2).

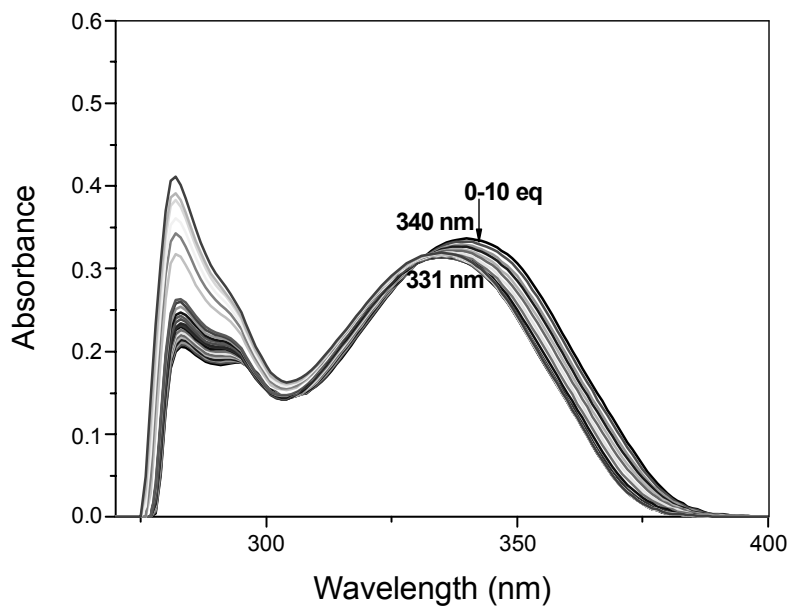

Figure 2. Changes in UV-vis spectra of $1(30 \mu \mathrm{M})$ upon the addition of $\mathrm{Hg}\left(\mathrm{ClO}_{4}\right)_{2}$ in EtOH:DMSO (v/v, 9:1).

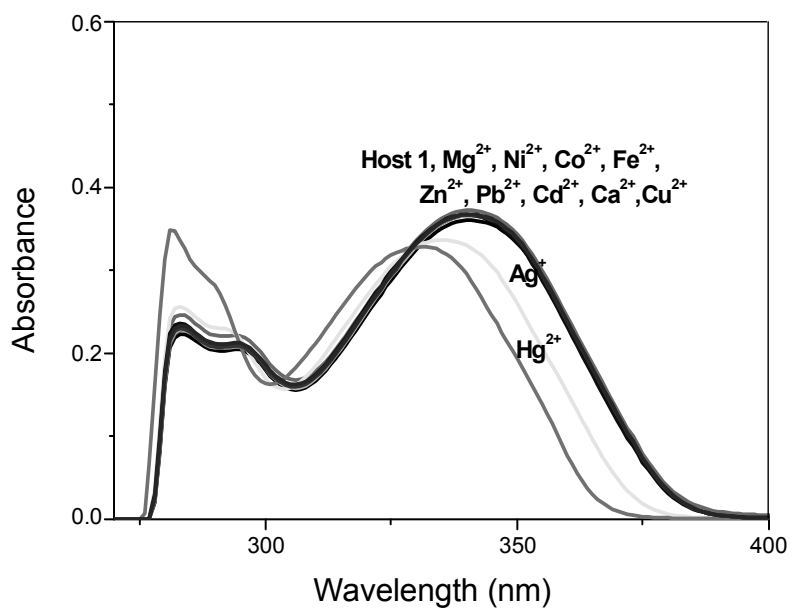

Figure 3. Changes in UV-vis spectra of $\mathbf{1}(30 \mu \mathrm{M})$ upon the addition of 10 equiv of different ions in EtOH:DMSO (v/v, 9:1). 


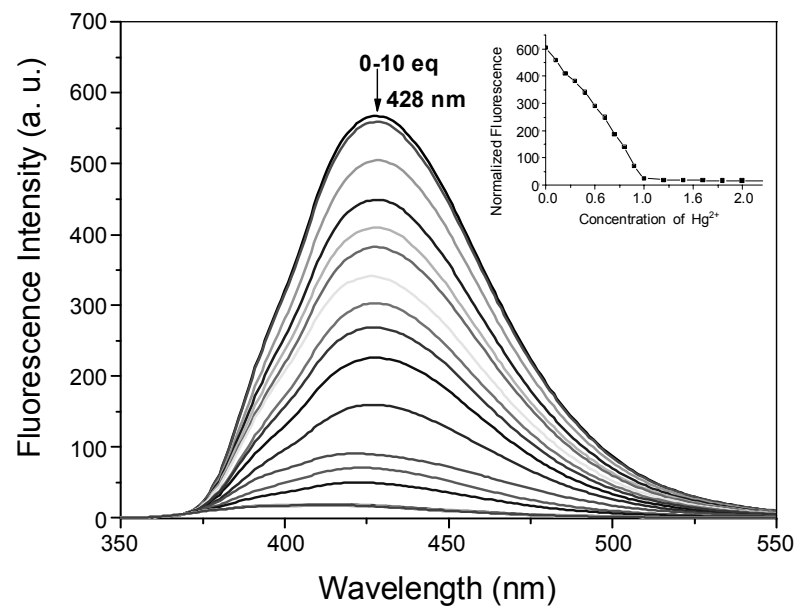

Figure 4. Changes in fluorescence spectra of $1(30 \mu \mathrm{M})$ upon the addition of $\mathrm{Hg}\left(\mathrm{ClO}_{4}\right)_{2}$ in EtOH:DMSO (v/v, 9:1). $\lambda_{\mathrm{ex}}=329 \mathrm{~nm}$. Inset: $\mathrm{mol}$ ratio plot of emission band at $428 \mathrm{~nm}$.

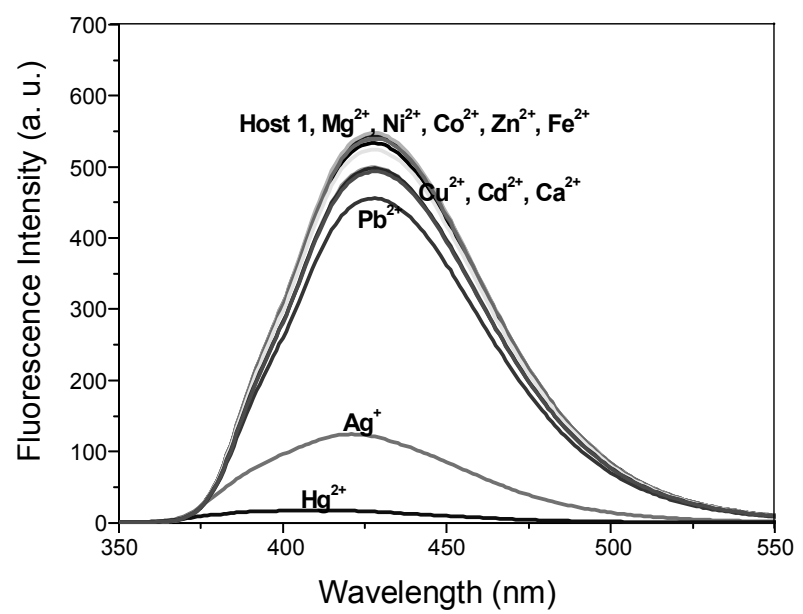

Figure 5. Fluorescence spectra of $1(30 \mu \mathrm{M})$ in $\mathrm{EtOH}: \mathrm{H}_{2} \mathrm{O}(\mathrm{v} / \mathrm{v}, 9: 1)$ upon addition of various metal ions (each concentration was $300 \mu \mathrm{M}$ ) with an excitation wavelength of $329 \mathrm{~nm}$.

electron donating character of this group disrupting the ICT from the oxygen to the coumarin fluorophore. This results in a blue-shift in absorption and a very fast and efficient nonradiative decay of the excited state that leads to fluorescence quenching.

In terms of electronic interaction, the cationic ion-dipole interactions of coumarin-thiazolobenzo-crown ether caused polarizations at the electronic level, which altered the fluorescence quantum yields significantly upon complex formation. Complexing of such compounds, therefore, showed remarkable changes in the emission intensity and excitation maxima, which were dependent on the cationic radii and the size of the macrocycle. ${ }^{30,2 \mathrm{c}}$ The binding mode of BTC (1) with $\mathrm{Hg}^{2+}$ from the results of fluorescence titration spectra (Figure 4 inset) are shown to be $1: 1$ with a binding constant of $3.7 \times 10^{4} \mathrm{M}^{-1}$ (Error estimated to be $\leq 10 \%)^{31}$

The selectivity and tolerance of $\mathbf{1}$ for $\mathrm{Hg}^{2+}$ over other metal ions was investigated by adding 10 equiv of metal ions to a 30 $\mu \mathrm{M}$ solution of 1 . In the case of $\mathrm{Hg}^{2+}$ the molecular fluorescence

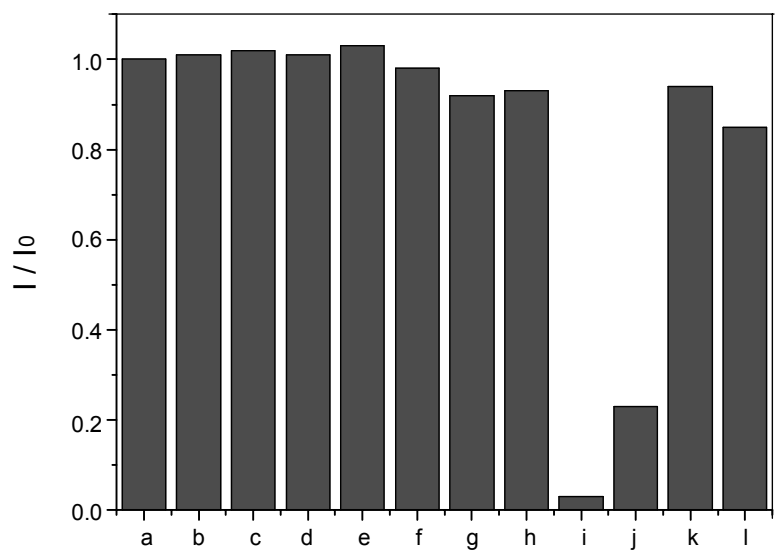

Figure 6. Quenching of fluorescence intensity of $1(30 \mu \mathrm{M})$ in EtOH: DMSO (v/v, 9:1) upon the addition of 10 equiv of respective metal ions. (a) 1 only, (b) $\mathbf{1}+\mathrm{Mg}^{2+}$, (c) $\mathbf{1}+\mathrm{Ni}^{2+}$, (d) $\mathbf{1}+\mathrm{Zn}^{2+}$, (e) $\mathbf{1}+\mathrm{Co}^{2+}$, (f) $\mathbf{1}+\mathrm{Fe}^{2+}$, (g) $1+\mathrm{Ca}^{2+}$, (h) $\mathbf{1}+\mathrm{Cd}^{2+}$, (i) $1+\mathrm{Hg}^{2+}$, (j) $\mathbf{1}+\mathrm{Ag}^{2+}$, (k) $\mathbf{1}+\mathrm{Cu}^{2+}$ and (l) $\mathbf{1}+\mathrm{Pb}^{2+}$.

Table 1. Photophysical properties of compounds 1, 2 and $\mathbf{3}$ in EtOH: DMSO (v/v, 9:1).

\begin{tabular}{|c|c|c|c|c|c|}
\hline \multirow{2}{*}{ Sensors } & \multicolumn{2}{|c|}{$\begin{array}{l}\text { Absorption Max. } \\
\text { nm }(\log \varepsilon)\end{array}$} & \multirow{2}{*}{$\begin{array}{r}\Delta \lambda \\
(\mathrm{nm})\end{array}$} & \multicolumn{2}{|c|}{$\begin{array}{l}\text { Emission Max. } \\
\mathrm{nm},\left(\mathrm{I} / \mathrm{I}_{0}\right)\end{array}$} \\
\hline & Free ligand & $\begin{array}{l}\text { Complex } \\
\text { with } \mathrm{Hg}^{2+}\end{array}$ & & Free ligand & $\begin{array}{l}\text { Complex } \\
\text { with } \mathrm{Hg}^{2+}\end{array}$ \\
\hline 1 & $340(4.09)$ & $331(4.04)$ & 9 & $428,(1.0)$ & $413,(0.02)$ \\
\hline 2 & $339(4.10)$ & $337(4.10)$ & 2 & $428,(1.0)$ & $429,(0.59)$ \\
\hline 3 & 345 (4.11) & 345 (4.11) & 0 & $432,(1.0)$ & $432,(0.97)$ \\
\hline
\end{tabular}

Table 2. Fluorescence-based binding constants of sensors $\mathbf{1}$ and $\mathbf{2}$.

\begin{tabular}{ccccc}
\hline Sensors & $\mathrm{Hg}^{2+}$ & $\mathrm{Ag}^{+}$ & $\mathrm{Pb}^{2+}$ & $\mathrm{Cu}^{2+}$ \\
\hline $\mathbf{1}$ & $3.71 \times 10^{4}$ & $1.52 \times 10^{4}$ & $2.07 \times 10^{3}$ & $8.12 \times 10$ \\
$\mathbf{2}$ & $3.73 \times 10^{3}$ & $4.57 \times 10^{3}$ & - & -
\end{tabular}

was quenched to the maximum level followed by $\mathrm{Ag}^{+}$which was only partially quenched. $\mathrm{Cu}^{2+}, \mathrm{Cd}^{2+}, \mathrm{Ca}^{2+}$ and $\mathrm{Pb}^{2+}$ show little quenching but there was no quenching in any other metal ions as shown in Figure 5.

The plot of fluorescence intensity ratio shows that maximum quenching took place in the case of $\mathrm{Hg}^{2+}$, followed by $\mathrm{Ag}^{+}$(Figure 6), there was little decrease in fluorescence intensity in the case of $\mathrm{Cu}^{2+}, \mathrm{Cd}^{2+}, \mathrm{Ca}^{2+}$ and $\mathrm{Pb}^{2+}$ and they were negligible in comparison to $\mathrm{Hg}^{2+}$. Table 2 shows that the binding was maximum with $\mathrm{Hg}^{2+}$ followed by $\mathrm{Ag}^{+}$. Also, when irradiated with a UV lamp at $365 \mathrm{~nm}, \mathrm{Hg}^{2+}$ produced full quenching while in the case of other cations fluorescence was not quenched as show in Figure 9.

To gain more insight into the chemo-sensing properties and mechanism of BTC (1) toward $\mathrm{Hg}^{2+}$ ions, $\mathrm{UV}$-vis absorption and fluorescence emission studies of OTC (2) with $\mathrm{Hg}\left(\mathrm{ClO}_{4}\right)_{2}$ and $\mathrm{AgClO}_{4}$ in EtOH:DMSO (v/v, 9:1) were carried out. The UVvis data in Figure $7 \mathrm{a}$ and $7 \mathrm{~b}$ shows that upon the addition of 10 


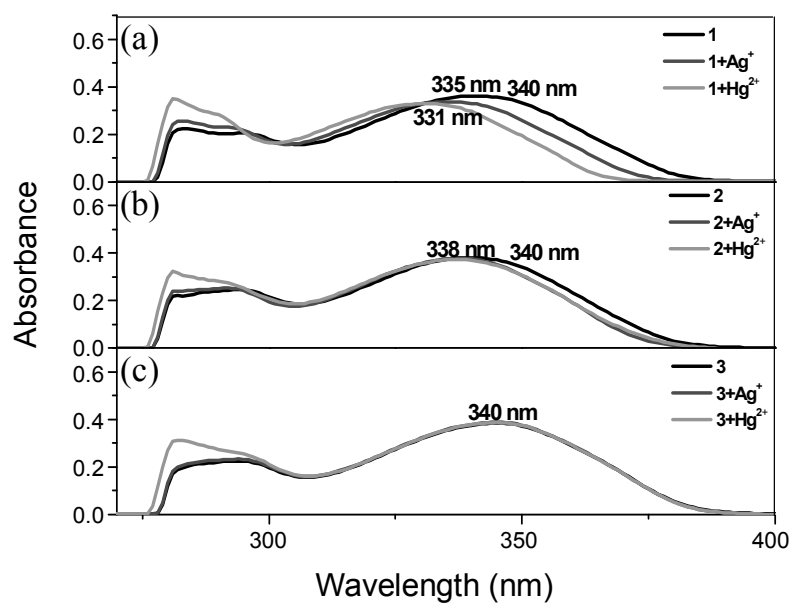

Figure 7. UV-vis spectra of (a) 1, (b) 2 and (c) $3(30 \mu \mathrm{M})$ in EtOH: DMSO $(\mathrm{v} / \mathrm{v}, 9: 1)$ in the presence of 10 equiv of $\mathrm{Hg}^{2+}$ and $\mathrm{Ag}^{+}$.

equiv of $\mathrm{Hg}^{2+}$ to both BTC (1) and OTC (2), only BTC (1) showed $9 \mathrm{~nm}$-blue shifts due to binding, while with OTC (2) the shift was negligible (Table 1).

In the fluorescence spectrum (Figure $8 \mathrm{a}$ and $8 \mathrm{~b}$ ) the sensor BTC (1) also underwent full quenching with $\mathrm{Hg}^{2+}$ while with OTC (2) the quenching was partial. These results indicated that the presence of the crown ether ring in BTC (1) produced stronger binding (Table 1).

It is known that coumarin itself can bind to a cation. ${ }^{32}$ In order to investigate the significance of the thiazolo-benzocrown ether, 5,6-dimethoxycoumarin 3 was prepared. The UV-vis spectrum of 3 showed no shift upon the addition of 10 equiv of $\mathrm{Hg}^{2+}$ (Figure 7c). The emission spectrum of $\mathbf{3}$ also showed no change on addition of $\mathrm{Hg}^{2+}$ (Figure 8c), which established the fact that the presence of the thiazolobenzo-crown ether acted as the main binding site with coumarin as the fluorophore.

To gain further insight into the nature of the $\mathrm{Hg}^{2+}$ complexation, cation recognition was evaluated using ${ }^{1} \mathrm{H}$ NMR in DMSO$d_{6}$. The partial ${ }^{1} \mathrm{H}$ NMR spectra of $\mathbf{1}$, upon the addition of $\mathrm{Hg}^{2+}$ ions, is shown in Figure 10. Notably, when 1 equiv of $\mathrm{Hg}^{2+}$ was added, the signals of $\mathrm{H}_{\mathrm{c}}(\Delta \delta, 0.19)$ and $\mathrm{H}_{d}(\Delta \delta, 0.29)$ of the coumarin ring, $\mathrm{H}_{\mathrm{b}}(\Delta \delta, 0.45)$ of the thiazole ring, the oxo-methylene protons of the crown ether $\mathrm{H}_{\mathrm{h}}(\Delta \delta, 0.63), \mathrm{H}_{\mathrm{i}}(\Delta \delta, 0.45), \mathrm{H}_{\mathrm{j}}(\Delta \delta$,

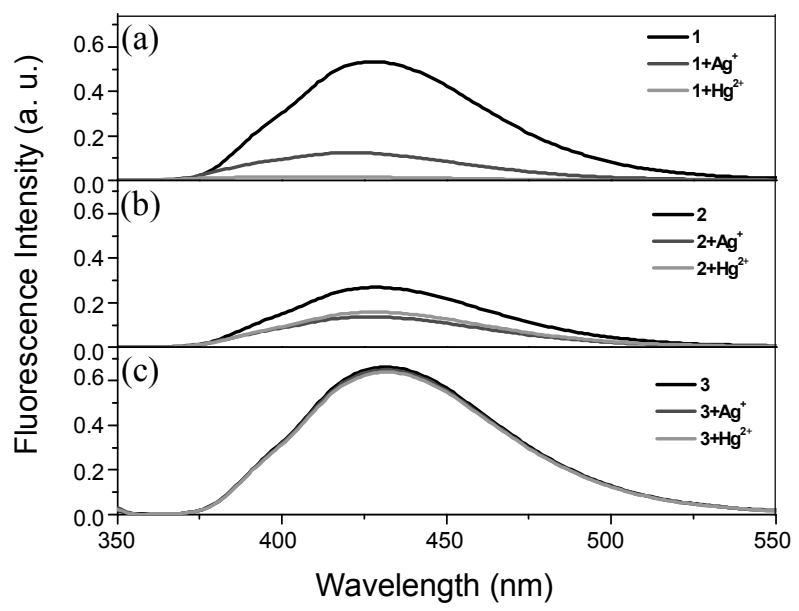

Figure 8. Fluorescence spectra of (a) 1, (b) 2 and (c) $3(30 \mu \mathrm{M})$ in EtOH:DMSO (v/v, 9:1) upon the addition of 10 equiv of $\mathrm{Hg}^{2+}$ and $\mathrm{Ag}^{+} \cdot \lambda_{\mathrm{ex}}=329,337$, and $345 \mathrm{~nm}$, respectively.

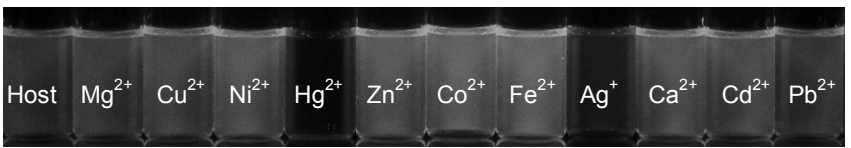

Figure 9. Fluorescence changes of $\mathbf{1}(30 \mu \mathrm{M})$ upon addition of $\mathbf{1}$ only, $\mathbf{1}+\mathrm{Mg}^{2+}, \mathbf{1}+\mathrm{Cu}^{2+}, \mathbf{1}+\mathrm{Ni}^{2+}, \mathbf{1}+\mathrm{Hg}^{2+}, \mathbf{1}+\mathrm{Zn}^{2+}, \mathbf{1}+\mathrm{Co}^{2+}, \mathbf{1}+\mathrm{Fe}^{+}, \mathbf{1}+$ $\mathrm{Ag}^{2+}, \mathbf{1}+\mathrm{Ca}^{2+}, \mathbf{1}+\mathrm{Cd}^{2+}$ and $\mathbf{1}+\mathrm{Pb}^{2+}$. Addition of 10 equiv of ions in EtOH:DMSO (v/v, 9:1).

$0.38)$, and $\mathrm{H}_{\mathrm{e}}(\Delta \delta, 0.38), \mathrm{H}_{\mathrm{f}}(\Delta \delta, 0.63)$ of the benzene ring were shifted downfield due to the deshielding effect created by binding with the metal ion.

\section{Conclusion}

In summary a new coumarin-thiazolobenzo-crown ether based chemosensor BTC (1) was developed for mercury ions that utilized the strong coordination of mercury ions on the crown oxygen and thiazole nitrogen. The complexation of $\mathrm{Hg}^{2+}$ disrupted the ICT from the oxygen donor to the coumarin fluorophore resulting in blue-shift in absorption and quenching of the fluorescence.

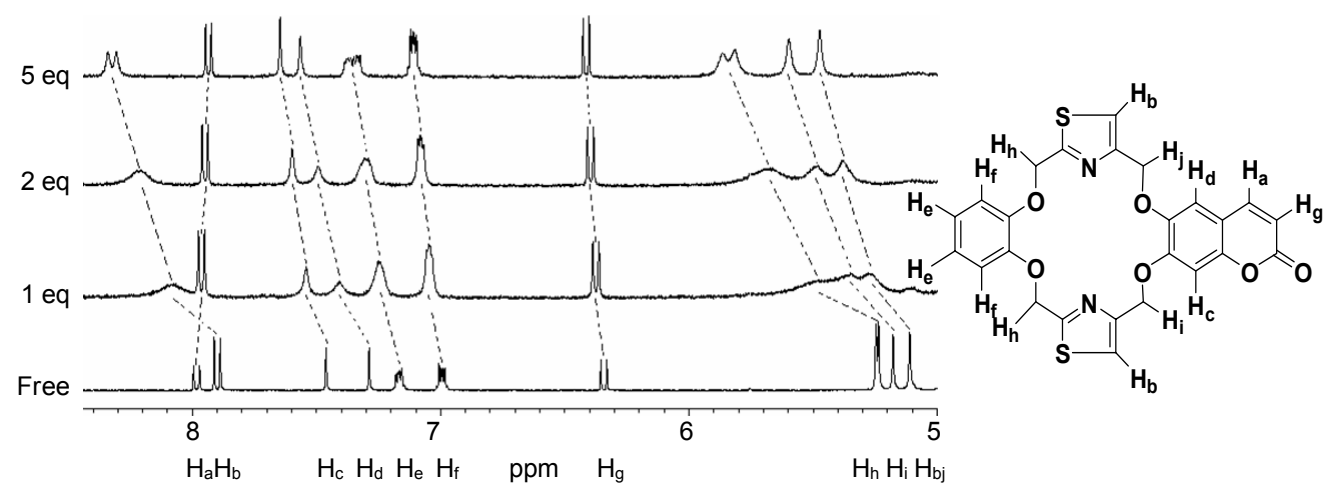

Figure 10. Partial ${ }^{1} \mathrm{H}$ NMR spectra of $\mathbf{1}$, with increasing the $\mathrm{Hg}\left(\mathrm{ClO}_{4}\right)_{2}$ concentration in DMSO- $d_{6}$. 
Acknowledgment. This research was supported by Kyungpook National University Research Fund, 2009.

\section{References}

1. Pedersen, C. J. J. Am. Chem. Soc. 1967, 89, 2495.

2. (a) Valeur, B.; Leray, I. Coord. Chem. Rev. 2000, 205, 3. (b) Berson, J.; Pouget, J.; Valuer, B. J. Phys. Chem. 1993, 97, 4552. (c) de Silva, A. P.; Gunaratne, H. Q. N.; Gunnlaugsson, T.; Huxley, A. J. M.; McCoy, C. P.; Rademacher, J. T.; Rice, T. E. Chem. Rev. 1997, 97, 1515. (d) Sause, L. H.; Larson, J. M. J. Am. Chem. Soc. 1977, 99, 307. (e) Alonso, M. T.; Brunet, E.; Hernandez, C.; RodrigezUbis, J. C. Tetrahedron Lett. 1993, 34, 7465.

3. (a) Kim, H.-S.; Koh, Y. K.; Choi, J. H. J. Heterocycl. Chem. 1998, 35, 177. (b) Kim, H.-S.; Park, H. J.; Oh, H. J.; Koh, Y. K.; Choi, J. H.; Lee, D. H.; Cha, G. S.; Nam, H. Anal. Chem. 2000, 72, 4683. (c) Kariuki, B. M.; Lee, S.-O.; Harris, K. D. M.; Kim, H.-S.; Do, K.-S.; Kim, K.-I. Cryst. Growth \& Des. 2002, 2, 309. (d) Kim, H.-S.; Do, K. S.; Kim, K. S.; Shim, J. H.; Cha, G. S.; Nam, H. Bull. Korean Chem. Soc. 2004, 25, 1465. (e) Kim, H.-S.; Bae, S. Y.; Kim, K. S.; Choi, J. H.; Choi, H. J.; Shim, J. H.; Cha, G. S.; Nam, H. Bull. Korean Chem. Soc. 2008, 29, 417.

4. Kwon, O. S.; Kim, H.-S. Supramolecular Chem. 2007, 19, 277.

5. (a) Leray, I.; Habib-Jiwan, J.-L.; Branger, C.; Soumillion, J.-Ph.; Valeur, B. J. Photochem. Photobiol. 2000, 135, 163. (b) Fery-Forgues, S.; Le Bris, M. T.; Guette, J. P.; Valeur, B. J. Phys. Chem. A 1988, $92,6233$.

6. Trenor, S. R.; Shultz, A. R.; Love, B. J.; Long, T. E. Chem. Rev. 2004, 104, 3059 .

7. Katerinopoulos, H. E. Current Pharmaceutical Design 2004, 10, 3835 .

8. (a) Habib Jiwan, J.-L.; Branger, C.; Soumillion, J.-Ph.; Valeur. B. J. Photochem. Photobiol. 1998, 116, 127. (b) Brunet, E.; GarciaLosada, P.; Rodriguez-Ubis, J.-C.; Juanes, O. Can. J. Chem. 2002, $80,169$.

9. (a) Badaoui, F. Z.; Bourson, J. Anal. Chim. Acta 1995, 302, 341. (b) Bourson, J.; Borrel, M.-N.; Valeur, B. Anal. Chim. Acta 1992, 257, 189.

10. (a) Vaidya, B.; Zak, J.; Bastiaans, G. J.; Porter, M. D. Anal. Chem. 1995, 67, 4101. (b) Alonso, M. T.; Brunet, E.; Hernandez, C.; Rodriguez-Ubis, J. C. Tetrahedron Lett. 1993, 34, 7465.

11. (a) Nolan, E. M.; Lippard, S. J. Chem. Rev. 2008, 108, 3443. (b) Czarnik, A. W. Acc. Chem. Res. 1994, 27, 302. (c) de Silva, A. P.; Fox, D. B.; Huxley, A. J. M.; Moody, T. S. Coord. Chem. Rev. 2000, 205, 41. (d) Chen, X.; Nam, S. W.; Jou, M. J.; Kim, Y. M.; Kim, S. J.; Park, S. S.; Yoon, J. Y. Organic Lett. 2008, 10, 5235. (e) Wei, J.; Wei, W. Chem. Comm. 2009, 3913. (f) Mello, J. V.; Finney, N. S. J. Am. Chem. Soc. 2005, 127, 10124. (g) Tatay, S.; Gavina, P.; Coronado, E.; Palomares, E. Org. Lett. 2006, 8, 3857. (h) Yoon, S.; Miller, E. W.; He, Q.; Do, P. H.; Chang, C. J. Angew. Chem. Int. Ed. 2007, 46, 6658.
12. Davidson, P. W.; Myers, G. J.; Cox, C.; Shamlaye, C. F.; Marsh, D. O.; Tanner, M. A.; Berlin, M.; Sloane-Reeves, J.; Cernichiari, E.; Choisy, O.; Choi, A.; Clarkson, T. W. Neurotoxicology 1995, 16, 677.

13. Takeuchi, T.; Morikawa, N.; Matsumoto, H.; Shiraishi, Y. Acta Neuropathol. 1962, 2, 40.

14. Harada, M. Crit. Rev. Toxicol. 1995, 25, 1.

15. (a) Lee, M. H.; Cho, B.-K.; Yoon, J.; Kim, J. S. Org. Lett. 2007, 9 , 4515. (b) Cheng, Y.; Zhang, M.; Yang, H.; Li, F.; Yi, T.; Huang, C. Dye\& Pig. 2008, 76, 775 .

16. Cheng, Y.; Zhao, D.; Zhang, M.; Liu, Z.; Zhou, Y.; Shu, T.; Li, F.; Yi, T.; Huang, C. Tetrahedron Lett. 2006, 47, 6413.

17. Talanov, V. S.; Roper, E. D.; Buie, N. M.; Talanova, G. G. Tetrahedron Lett. 2007, 48, 8022.

18. Choi, M. G.; Kim, Y. H.; Namgoong, J. E.; Chang, S.-K. Chem. Commun. 2009, 3560

19. Leray, I.; Valeur, B. Eur. J. Inorg. Chem. 2009, 3525.

20. Wang, H.; Chan, W. Tetrahedron 2007, 63, 8825.

21. (a) Santra, M.; Ryu, D.; Chatterjee, A.; Ko, S.-K.; Shin, I.; Ahn, K. H. Chem. Commun. 2009, 2115. (b) Jana, A.; Kim, J. S.; Jung, H. S.; Bharadwaj, P. K. Chem. Commun. 2009, 4417.

22. Yang, H.; Zhou, Z.; Xu, J.; Li, F.; Yi, T.; Huang, C. Tetrahedron 2007, 63, 6732 .

23. (a) Lee, M. H.; Lee, S. W.; Kim, S. H.; Kang, C.; Kim, J. S. Org. Lett. 2009, 11, 2101. (b) Dolci, L. S.; Marzocchi, E.; Montalti, M.; Prodi, L.; Monti, D.; Di Natale, C.; D'Amico, A.; Paolesse, R. Biosens. Bioelectron. 2006, 22, 399.

24. (a) Choi, M. G.; Ryu, D. H.; Jeon, H. L.; Cha, S.; Cho, J.; Joo, H. H.; Hong, K. S.; Lee, C.; Ahn, S.; Chang, S.-K. Org. Lett. 2008, 10, 3717. (b) Nolan, E. M.; Racine, M. E.; Lippard, S. J. Inorg. Chem. 2006, 45, 2742. (c) Nolan, E. M.; Lippard, S. J. J. Am. Chem. Soc. 2003, 125, 14270. (d) Nolan, E. M.; Lippard, S. J. J. Am. Chem. Soc. 2007, 129, 5910.

25. (a) Erk, C.; Fresenius, Z. Anal. Chem. 1983, 316, 477. (b) Erk, C. J. Phys. Chem. 1990, 94, 8617.

26. Sousa, L. R.; Larson, M. J. Am. Chem. Soc. 1983, 100, 477.

27. Valeur, B. Molecular Luminescence Spectroscopy; Schulman, S. G., Ed., John Wiley: New York, 1993; Part 3, pp 25-84.

28. Schneider, H. J.; Dur, H. Frontiers in Supramolecular Chemistry and Photochemistry; VCH: Weinheim, 1991.

29. Tran, A. H.; Miller, D. O.; Georghiou, P. E. J. Org. Chem. 2005, 70, 1115.

30. (a) Desvergne, J. P.; Czarnik, A. W. NATO ASI Series; Kluwer Academic Publishers: Dordrecht, 1997; Series C, Vol. 492. (b) de Silva, A. P.; Gunaratne, H. Q. N.; Gunnalaugsson, T.; Manabe, O. J. Chem. Soc. Chem. Commun. 1996, 967.

31. (a) Connors, K. A. Binding Constants: the Measurement of Molecular Complex Stability; Wiley: New York, 1987; pp 21-101; 339343. (b) gnuplot, www.gnuplot.com.

32. Miyaji, H.; Kim, H.-K.; Sim, E.-K.; Lee, C.-K.; Cho, W.-S.; Sessler, J. L.; Lee, C.-H. J. Am. Chem. Soc. 2005, 127, 12510. 